JPdK Volume 1 Nomor 1 Tahun 2019 Halaman 11-24

JURNAL PENDIDIKAN dan KONSELING

Research \& Learning in Faculty of Education

\title{
Peningkatan Keterampilan Menulis Puisi dengan Menggunakan Model Experiental Learning pada Siswa Kelas III Sekolah Dasar
}

\author{
Gustina $^{1}$, Putri Hana Pebriana ${ }^{2}$, Zulhendri ${ }^{3}$ \\ Program Studi Pendidikan Guru Sekolah Dasar \\ Fakultas Ilmu Pendidikan \\ Universitass Pahlawan Tuanku Tambusai \\ Email: Gustina699@gmail.com
}

\begin{abstract}
Abstrak
Penelitian ini dilatar belakangi oleh rendahnya hasil keterampilan menulis siswa pada mata pelajaran Bahasa Indonesia pada materi puisi di kelas III SDN TI 030 Batu Belah. Salah satu solusi untuk mengatasi masalah ini adalah dengan menggunakan model pembelajaran Experiential Learning. Tujuan penelitian ini untuk mendeskripsikan peningkatan keterampilan menulis siswa pada mata pelajaran Bahasa Indonesia materi puisi dengan menggunakan Experiential Learning. pada siswa kelas III SDN TI 030 Batu Belah. Metode Penelitian ini adalah Penelitian Tindakan Kelas (PTK) yang dilaksanakan dalam dua siklus. Setiap siklus terdiri dari dua pertemuan dan empat tahapan, yaitu perencanaan, pelaksanaan, observasi, refleksi, dan waktu penelitian dilaksanakan pada bulan Juli 2019. Subjek penelitian ini siswa kelas III yang berjumlah 25 orang, dengan jumlah siswa laki-laki 15 orang, dan siswa perempuan berjumlah 10 orang. Teknik pengumpulan data berupa dokumentasi, observasi, dan tes. Hasil penelitian ini menunjukkan bahwa hasil keterampilan menulis siswa pada mata pelajaran Bahasa Indonesia materi puisi di kelas III SDN TI 030 Batu Belah pada siklus I tergolong cukup dengan rata-rata 60,00 . Selanjutnya dari 25 orang siswa hanya 14 orang yang tuntas dengan ketuntasan klasikal 56\% dan yang tidak tuntas 11 orang. Pada siklus II tergolong baik dengan rata-rata 78,80 dari 25 orang siswa terdapat 23 orang siswa yang tuntas dengan ketuntasan klasikal $92 \%$ dan yang tidak tuntas 2 orang. Indikator penilaian Experiential Learning diksi tema dan amanat. Dengan demikian dapat disimpulkan bahwa dengan menggunakan model pembelajaran Experiential Learning. dapat meningkatkan keterampilan menulis siswa pada mata pelajaran Bahasa Indonesia materi puisi pada siswa kelas III SDN TI 030 Batu Belah.
\end{abstract}

Kata Kunci : Keterampilan menulis, Model Experiential Learning, Puisi

PENDAHULUAN

juga di pandang sebagai salah satu aspek

Pendidikan memiliki peranan

penting dalam mencerdaskan kehidupan

bangsa. Melalui pendidikan inilah suatu

bangsa dapat menjadi bangsa yang

tangguh, mandiri, berkarakter dan

berdaya saing. Selain itu, pendidikan

JURNAL PENDIDIKAN DAN KONSELING VOLUME 1 NOMOR 1 TAHUN 2019 
yang memiliki peranan pokok dalam mempersiapkan sekaligus membentuk generasi muda dimasa yang akan datang. Keberhasilan pembangunan suatu bangsa ditentukan oleh kualitas pendidikan warga bangsa tersebut. Karena dengan pendidikan yang baik manusia dapat mencapai kesejahteraan 
hidup, mengembangkan potensi dirinya, mewujudkan kehidupan lebih baik dan berpartisipasi secara aktif dalam pembangunan. Hal itu disebabkan dalam fungsi dan tujuan pendidikan nasional yang tercantum dalam Undang - Undang Republik Indonesia (UU RI) tentang sistem pendidikan nasional pasal 3 No.20 tahun 2003 :

Pendidikan Nasional berfungsi mengembangkan kemampuan dan membentuk watak serta peradaban bangsa yang bermartabat dalam rangka mencerdaskan kehidupan bangsa,bertujuan untuk berkembangnya potensi peserta didik agar menjadi manusia yang beriman dan bertakwa kepada Tuhan Yang Maha Esa, berakhlak mulia, sehat, berilmu, cakap, keratif, mandiri dan menjadi warga yang Negara yang demokratis serta bertanggung jawab. Tujuan pendidikan nasional dapat terwujud apabila sistem pendidikan tidak hanya ditekankan pada hasil belajar peserta didik tetapi juga pada proses belajar dari peserta didik itu sendiri untuk menumbuhkan kemampuan berpikir, bekerja dan bersikap kritis guna mengembangkan potensi peserta didik.

Pembelajaran Bahasa Indonesia di sekolah dasar adalah upaya membelajarkan siswa untuk meningkatkan kemampuan berkomunikasi baik secara lisan maupun tertulis (Depdikbud, 1995). Pembelajaran Bahasa Indonesia di sekolah dasar mencakup penguasaan empat aspek keterampilan berbahasa yaitu keterampilan menyimak (listening skills), keterampilan berbicara (speaking skills), keterampilan membaca (reading skills), dan keterampilan menulis (writing skills) (Tarigan, 2008: 1). Keempat aspek keterampilan berbahasa tersebut saling berhubungan dan secara mutlak harus dikuasai oleh siswa sebagai syarat ketuntasan pembelajaran Bahasa
Indonesia. Pembelajaran bahasa Indonesia diarahkan untuk meningkatkan kemampuan peserta didik untuk berkomunikasi dalam bahasa Indonesia dengan baik dan benar. Hal tersebut dilakukan baik secara lisan maupun tulis, serta menumbuhkan apresiasi terhadap hasil karya kesastraan manusia Indonesia.

Bahasa Indonesia adalah alat komunikasi yang dipergunakan oleh masyarakat Indonesia untuk keperluan sehari-hari, misalnya belajar, bekerja sama dan berinteraksi. Bahasa Indonesia merupakan bahasa nasional dan bahasa resmi di Indonesia. Bahasa nasional adalah bahasa yang menjadi standar di Negara Indonesia. Sebagai bahasa nasional, bahasa Indonesia tidak mengikat pemakainya untuk sesuai dengan kaidah dasar. Bahasa Indonesia digunakan secara non resmi, santai dan bebas. Dalam pergaulan sehari antar warga yang di pentingkan adalah makna yang disampaikan. Pemakai bahasa Indonesia dalam konteks bahasa nasional dapat menggunakan dengan bebas menggunakan ujarannya baik lisan maupun tulis. Salah satu aspek keterampilan berbahasa yang harus diperhatikan yaitu keterampilan menulis. Keterampilan tersebut penting mengingat dalam kehidupan sehari siswa tidak akan lepas dari kegiatan menulis.

Menulis adalah kegiatan penyampaian pesan (komunikasi) dengan menggunakan bahasa tulis sebagai alat atau medianya. Menulis adalah kegiatan komunikasi berupa penyampaian pesan secara tertulis kepada pihak lain (Suparno, 2009 :1.3). Menurut Tarigan (2008: 2) keterampilan berbahasa menulis merupakan keterampilan yang dipergunakan untuk berkomunikasi secara tidak langsung dengan lawan bicaranya. Selain itu, keterampilan berbahasa menulis juga termasuk kegiatan yang produktif dan 
ekspresif. Pembelajaran Bahasa Indonesia di sekolah hendaknya mampu membantu siswa meningkatkan keterampilan berbahasa menulis anak dengan baik secara maksimal.

Keterampilan menulis merupakan salah satu materi dan bidang aktivitas yang memegang peran sangat penting yang dapat dilakukan siswa dalam pembelajaran bahasa Indonesia di Sekolah Dasar (SD). Menulis merupakan bagian dari empat keterampilan yang ada dalam pembelajaran bahasa Indonesia yang tentu saja harus dikuasai dengan baik oleh siswa. Menulis juga merupakan salah satu kompetensi yang tidak hanya diajarkan dalam satu jenjang pendidikan saja, namun diajarkan mulai dari jenjang pra sekolah hingga sekolah menengah atas. Menulis adalah menurunkan atau melukiskan lambang-lambang grafis menggambarkan suatu bahasa yang dipahami oleh seseorang sehingga orang lain dapat membaca lambing grafis tersebut (Tarigan, 2008: 22).

Keterampilan menulis merupakan keterampilan yang bersifat produktif, artinya keterampilan menulis merupakan keterampilan yang menghasilkan yaitu menghasilkan tulisan. Menulis secara umum dapat diartikan sebagai suatu kegiatan penyampaian pesan (komunikasi) dengan menggunakan bahasa tulis sebagai alat atau medianya. Sebagai suatu keterampilan berbahasa, menulis merupakan kegiatan yang kompleks karena penulis dituntut untuk dapat menyusun dan mengorganisasikannya dalam formulasi ragam bahasa tulis. Melalui kegiatan menulis paragraf siswa dapat mengkomunikasikan ide/gagasan dan pengalamannya. Siswa juga dapat meningkatkan dan memperluas pengetahuannya melalui tulisannya.

Pembelajaran Bahasa Indonesia di Sekolah Dasar memiliki tujuan untuk mencapai kompetensi yang harus dikuasai oleh siswa. Tujuan mata pelajaran Bahasa Indonesia menurut tim penyusun KTSP (2007:54) untuk satuan Pendidikan dasar SD/ MI adalah:

1. Berkomunikasi secara efektif dan efisien sesuai dengan etika yang berlaku, baik secara lisan maupun tertulis.

2. Menghargai dan bangga menggunakan bahasa Indonesia sebagai bahasa persatuan dan bahasa Negara.

3. Memahami bahasa Indonesia dan menggunakannya dengan tepat dan kreatif untuk berbagai tujuan.

4. Menggunakan bahasa Indonesia untuk meningkatkan kemampuan intelektual, serta kematangan emosional dan social.

5. Menikmati dan memanfaatkan karya sastra untuk memperluas wawasan,memperluas budi pekerti, serta meningkatkan pengetahuan dan kemampuan berbahasa.

6. Menghargai dan membangun sastra Indonesia sebagai khasanah budaya dan intelektual manusia Indonesia.

Berdasarkan uraian diatas dapat disimpulkan bahwa tujuan pembelajaran Bahasa Indonesia di sekolah dasar adalah untuk meningkatkan kemampuan siswa berkomunikasi secara lisan dan tertulis, dapat meningkatkan kemampuan intelektual yang dimiliki serta menghargai Bahasa Indonesia sebagai Bahasa Indonesia serta untuk meningkatkan karakter siswa.

Dalam pengajaran Bahasa Indonesia di sekolah pada prinsipnya bertujuan agar para siswa memiliki empat keterampilan berbahasa, yaitu keterampilan menyimak, berbicara, membaca dan menulis. Dilihat dari empat macam keterampilan berbahasa di atas, keterampilan menulis merupakan keterampilan berbahasa yang paling akhir yang harus benar dikuasai oleh 
siswa. Dibandingkan dengan tiga keterampilan Seperti yang telah dijelaskan di atas, bahwa aspek berbahasa ada empat yaitu ketrampilan menyimak (listening skills), keterampilan berbicara (speaking skills), keterampilan membaca (reading skills), dan keterampilan menulis (writing skills). Penguasaan keterampilan berbahasa tersebut terjadi secara bertahap. Awalnya, anak mengenal bahasa melalui menyimak. Setelah menyimak, anak tersebut berusahauntuk berbicara menirukan bahasa yang disimak. Tahap berikutnya, anak akan berlatih membaca dan berusaha untuk mengenal bentuk tulisan (wacana). Setelah itu, anak akan berusaha untuk menulis. Jadi, antar keempat keterampilan berbahasa tersebut memiliki keterkaitan yang erat. Empat keterampilan tersebut merupakan satu kesatuan, merupakan catur tunggal (Tarigan, 2008:2). Hubungan antar jenis keterampilan berbahasa ini sangat berkaitan dengan proses penciptaan puisi.

Berdasarkan Observasi lapangan yang dilakukan peneliti pada saat proses pembelajaran di SDTI 030 Batu Belah pada hari rabu tanggal 20 Februari 2019 di kelas III pada mata pelajaran Bahasa Indonesia memberikan gambaran bahwa keterampilan menulis puisi masih tergolong sangat rendah dengan rata-rata mencapai 64,43 dengan kategori kurang. Siwa yang mendapat nilai baik (71-84) berjumlah 9 orang, siwa yang mendapat nilai cukup (69-79) berjumlah 13 orang, siswa yang mendapat nilai kurangkurang (<65) berjumlah 9 orang. Rendahnya keterampilan menulis puisi siswa, yakni pembelajaran menulis puisi dari guru kurang kreatif dalam memilih metode atau teknik untuk pembelajaran, siswa sulit memilih kata-kata atau diksi, siswa mempunyai pemikiran bahwa menulis puisi merupakan hal yang sulit, terbatasnya ide yang dituangkan, kurangnya kreativitas, imajinasi, dan sulit berkonsentrasi untuk menuangkan ke dalam puisi. Guru masih menggunakan model yang konvensional, guru kurang dapat menarik perhatian minat siswa untuk belajar sehingga siswa merasa enggan untuk terlibat secara aktif, selain itu guru kurang menerapkan media pembelajaran yang menarik minat siswa untuk belajar dan kurangnya perhatian siswa terhadap penjelasan guru, kebanyakan siswa justru rebut dan berbicara dengan teman sebangkunya, kurangnya penguasaan kosa kata yang juga berdampak pada rendahnya keterampilan menulis puisi sehingga siswa kesulitan mengungkapkan ide maupun gagasan. Minimnya penguasaan kosa kata mengakibatkan siswa menjadi kesulitan dalam merangkai sajak dalam penulisannya. Hal ini mengakibatkan tugas menulis puisi yang diberikan oleh guru pun menjadi sulit untuk diselesaikan oleh siswa.

Berbagai permasalahan yang ditemukan dalam pembelajaran keterampilan menulis puisi di kelas III SDTI Batu Belah perlu segera mendapatkan solusi agar tidak menghambat pencapaian hasil belajar siswa. Salah satu solusi untuk mengatasi masalah-masalah yang telah diuraikandi atas yaitu perlunya penerapan suatu model pembelajaran yang inovatif dan tepat dan sesuai dengan karakteristik siswa demi keberhasilan pembelajaran keterampilan menulis puisi pada mata pelajaran Bahasa Indonesia di kelas III SDTI Batu Belah. Maka dari itu bahwa untuk mengatasi berbagai permasalahan tersebut akan diterapkan suatu model pembelajaran baru yang kreatif, inovatif, dan dapat melibatkan siswa secara aktif dalam proses pembelajaran yaitu model Experiential Learning

Model experiential learning adalah suatu model proses belajar 
mengajar yang mengaktifkan pembelajaran untuk membangun pengetahuan dan keterampilan melalui pengalamannya secara langsung. dalam hal ini, experiential learning menggunakan pengalaman sebagai katalisator untuk menolong pembelajaran mengembangkan kapasitas kemampuan dalam proses pembelajaran Wahyuni (2007: 165). Selanjutnya menurut Silberman (2014:

10) mengemukakan bahwa: model experiential learning adalah keterlibatan siswa dalam kegiatan konkret yang membuat mereka mampu untuk mengalami apa yang tengah mereka pelajari dan kesempatan untuk merefleksikan kegiatan tersebut.

Model ini akan bermakna dalam pembelajaran berperan serta dalam melakukan kegiatan. Kemudian, mereka mendapatkan pemahaman serta menuangkannya dalam bentuk lisan atau tulisan sesuai dengan tujuan pembelajaran. Langkah ini bagi guru dalam experiential learning adalah memikirkan atau merancang aktifitas pengalaman belajar seperti apa yang harus terjadi pada diri siswa baik individu maupun kelompok. Aktifitas pembelajaran harus berfokus pada peserta belajar (student-centered learning). Dengan demikian, apa yang harus kita lakukan, apa yang harus mereka lakukan, apa yang harus kita katakan atau sampaikan harus secara detail kita rancang dengan baik.

Begitu pula dengan media dan alat bantu pembelajaran lain yang yang dibutuhkan juga harus benar-benar telah tersedia dan siap untuk digunakan (Roem,1986). Metode Experiential learning tidak hanya memberikan wawasan pengetahuan konsep-konsep saja. Namun, juga memberikan pengalaman yang nyata yang akan membangun keterampilan melalui penugasan nyata. Selanjutnya, metode ini akan mengakomodasi dan memberikan proses umpan balik serta evaluasi antara hasil penerapan dengan apa yang seharusnya dilakukan.

Dengan demikian, dari pernyataan di atas dapat diambil sebuah pengertian bahwa experiential learning adalah suatu metode proses belajar mengajar yang mengaktifkan pembelajar untuk membangun pengetahuan dan keterampilan melalui pengalamannya secara langsung. Dalam hal ini, Experiential learning menggunakan pengali katalisator untuk membantu pembelajar mengembangkan kapasitas dan kemampuannya dalam proses pembelajaran sehingga pembelajar terbiasa berpikir kreatif. Experiential learning adalah suatu proses dimana siswa mengkonstuksi atau menyusun pengetahuan keterampilan dan nilai dari pengalaman langsung. Adapun prinsip dasar eksperiental learning adalah sebagai berikut:

Prosedur pembelajaran dalam experiential learning terdiri dari 4 tahapan, yaitu; 1) tahapan pengalaman nyata, 2) tahap observasi refleksi, 3) tahap konseptualisasi, dan 4) tahap implementasi Berdasarkan uraian yang dikemukakan di atas, penulis merasa perlu untuk mengadakan penelitian tentang "Peningkatan Keterampilan Menulis Puisi dengan Menggunakan Model Experiential Learning pada Siswa Kelas III Sekolah Dasar.

Berdasarkan Latar belakang masalah diatas dapat dirumuskan masalah dalam penelitian ini, yaitu: Bagaimanakah peningkatan keterampilan menulis puisi dengan menggunakan model Experiential Learning siswa kelas III SDTI 030 Desa Batu Belah? 


\section{METODOLOGI PENELITIAN}

Penelitian ini menggunkan metode kualitatif yang berjenis Penelitian Tindakan Kelas (Class Action Research). Arikunto, (2006) dalam (Iskandar, 2009:20) mengatakan bahwa, "Penelitian Tindakan Kelas merupakan suatu pencermatan terhadap kegiatan pembelajaran berupa sebuah tindakan, yang sengaja dimunculkan dan terjadi dalam sebuah kelas secara bersamaan". Selain itu, Iskandar (2009:21) juga menyatakan bahwa: "Penelitian Tindakan Kelas adalah suatu kegiatan penelitian ilmiah yang dilakukan secara rasional, sistematis dan empiris reflektif terhadap berbagai tindakan yang dilakukan oleh guru atau dosen (tenaga pendidik), kolaborasi (tim peneliti) yang sekaligus sebagai peneliti, sejak disusunnya suatu perencanaan sampai penilaian terhadap tindakan nyata di dalam kelas yang berupa kegiatan belajar mengajar, untuk memperbaiki dan meningkatkan kondisi pembelajaran yang dilakukan".

subjek penelitian adalah seluruh siswa kelas III SDTI 030 Batu Belah dengan jumlah siswa 25 orang, yang terdiri dari 15 orang siswa laki-laki dan 10 orang siswa perempuan.

Penelitian tindakan kelas ini dilaksanakan dua siklus. Siklus pertaman dilaksanakan dua kali pertemuan dan siklus kedua juga dua kali pertemuan. Alokasi waktu pada setiap pertemuan 70 menit. Pelaksanaan masing-masing siklus mengikuti tahaptahap

perencanaan,tindakan,observasi,dan refleksi.

Berhasil tidaknya penelitian dilakukan dapat diketahui dari data yang diperoleh. Terkait dengan itu, untuk memperoleh data dalam menjawab masalah penelitian dapat dilakukan dengan menggunakan instrumen penelitian yaitu sebuah alat bantu yang dipilih peneliti dalam kegiatan pengumpulan data, agar kegiatan tersebut berjalan dengan sistematis. Arikunto (dalam Sarjana, 2010:43). Data penelitian yang digunakan dalam penelitian tindakan kelas ini berupa observasi dan tes sebagai metode utama untuk memperoleh data.

Instrumen penelitian adalah alat atau fasilitas yang digunakan peneliti dalam mengumpulkan data agar pekerjaannya lebih mudah dan hasilnya lebih baik, dalam arti lebih cermat, lengkap dan sistematis sehingga lebih mudah diolah. Agar penelitian ini dapat dilaksanakan dengan baik maka perlu dipersiapkan instrument penelitian. Adapun instrumen penelitian yang perlu dipersiapkan sebagai berikut:

1. Instrumen

Perencanaan

Pembelajaran berfungsi untuk menilai perencanaan pembelajaran yang akan dinilai oleh observer pada setiap pembelajaran siklus I dan siklus II.

2. Lembar Observasi berfungsi untuk menilai kegiatan yang dilakukan peneliti dalam melaksanaan penelitian, obsever akan mengisi lembaran observasi yang mencatat kegiatan peneliti dari awal sampai akhir. Lembar observasi terbagi dua bagian yaitu lembar observasi aktivitas guru dan lembar obsevasi aktivitas siswa.

3. Rublik penilaian menulis puisi berfungsi untuk mengetahui peningkatan keterampilan menulis puisi siswa telah mencapai KKM atau belum, peneliti menggunakan rubrik penilaian menulis puisi yang dibuat oleh peneliti.

Teknik pengumpulan data merupakan langkah yang paling strategis dalam penelitian karena tujuan utama dari penelitian adalah untuk mendapatkan data. Adapun teknik 
pengumpulan data yang akan diambil sebagai berikut:

1. Teknik dokumentasi yang digunakan dalam penelitian ini adalah menganalisis RPP. Hasil dari dokumentasi ini digunakan untuk mendeskripsikan perencanaan pelaksanaan pembelajaran dengan penerapan model Experiential Learning

2. Teknik observasi digunakan untuk mengumpulkan data tentang aktivitas guru dan siswa ketika proses pembelajaran berlangsung dengan menggunakan penerapan model Experiental Learning.

3. Teknik evaluasi digunakan untuk mengumpulkan data tentang keterampilan menulis. Tes evaluasi ini menggunakan tes formatif berupa Lembar Tugas Siswa (LTS) yang diberikan kepada siswa untuk menulis keterampilan puisi.

Analisis data yang digunakan dalam penelitian ini adalah analisis kuantitatif dan kualitatif. Analisis kuantitatif digunakan untuk menganalisis nilai rata-rata dan persentase skor nilai keterampilan menulis puisi deskriptif siswa.

b. Ketuntasan Klasikal

Jika ketuntasan klasikal siswa telah mencapai $80 \%$ dari seluruh siswa, maka secara klasikal telah tercapai dengan baik (Wardhani, 2007:25).

$\mathrm{KK}=\frac{\text { Jumlah Siswa yang Tuntas }}{\text { Jumlah Seluruh Siswa }} \mathrm{X}$ 100

(Wardhani, dkk, 2007:25)

Keterangan:

KK : Ketuntasan Klasikal Adapun kriteria proses pembelajaran keterampilan
Sedangkan anlisis kualitatif digunakan untuk menganalisis lembar observasi kegiatan siswa dan guru saat proses pembelajaran. Berikut penjelasanya:

1. Analisis kuantitatif

a. Ketuntasan Belajar Individu

Adapun pedoman rubrik yang digunakan dalam penilaian keterampilan menulis puisi siswa SDTI 030 Batu Belah adalah sebagai berikut:

Adapun aspek yang dinilai ada 3 yaitu :

1. Diksi

2. Tema

3. Amanat/pesan

Siswa dikatakan tuntas apabila nilainya mencapai KKM atau lebih dari KKM yaitu 75 . Untuk menentukan ketuntasan yang dicapai siswa peneliti menggunakan rumus yang digunakan yaitu :

$$
=\frac{\text { KBSI }}{\text { Skor yang diperoleh siswa }} \times 100
$$

menulis puisi dapat di lihat pada table berikut:

Tabel 3.5

Interval Ketuntasan klasikal

\begin{tabular}{|c|c|c|}
\hline No & Interval & Kategori \\
\hline 1 & $90-100 \%$ & Baik Sekali \\
\hline 2 & $80-89 \%$ & Baik \\
\hline 3 & $70-79 \%$ & Cukup \\
\hline 4 & $60-69 \%$ & Kurang \\
\hline 5 & $<59 \%$ & $\begin{array}{c}\text { Sangat } \\
\text { Kurang }\end{array}$ \\
\hline
\end{tabular}

Sumber: (Riduan \& Sunarto, 2012:20) 


\section{HASIL PENELITIAN DAN PEMBAHASAN}

\section{A. Deskripsi Pratindakan}

Sebelum dilakukan tindakan, peneliti melakukan observasi yaitu untuk mengetahui kemampuan siswa dalam menulis puisi. Data dari observasi dan wawancara awal yang dilakukan dengan guru kelas III SDTI 030 Batu Belah kecamatan Kampar kabupaten Kampar, peneliti menganalisis data keterampilan menulis puisi siswa pratindakan, dengan tujuan untuk mengetahui peningkatan hasil keterampilan menulis siswa pada pembelajaran Bahasa Indonesia pada materi Puisi. Hasil pratindakan digunakan sebagai

Berdasarkan table 4.1 di atas, diketahui bahwa nilai keterampilan menulis siswa sebelum tindakan dari 30 orang siswa hanya $9(29 \%)$ siswa yang mencapai KKM, dan $22(71 \%)$ siswa belum mencapai nilai KKM. Hasil nilai keterampilan menulis siswa sebelum tindakan ini, masih belum mencapai kriteria ketuntasan klasikal yang telah ditetapkan yaitu $80 \%$, sehingga akan dilakukan perbaikan dengan penerapan model pembelajaran Experiential Learning dan diharapkan adanya peningkatan hasil keterampilan menulis siswa pada pembelajaran Bahasa Indonesia.

\section{B. Deskripsi Hasil Tindakan Tiap} Siklus

\begin{tabular}{lrr}
\multicolumn{3}{r}{ Perbandingan keterampilan } \\
menulis puisi dengan \\
menggunakan model Experiential
\end{tabular}

perbandingan keterampilan menulis puisi siswa setelah menggunakan model pembelajaran Experiential Learning pada mata pelajaran Bahasa Indonesia materi Puisi kelas III SDN TI 030 Batu Belah.

Dalam menentukan kriteria penilaian tentang hasil, maka peneliti menggunakan 5 kriteria (Riduan \& Sunarto, 2012:20) yaitu kategori baik sekali dengan presentase $90 \%$ $100 \%$, kategori baik dengan presentase $80 \%$ - 89\%, kategori cukup dengan presentase $70 \%-79 \%$, kategori kurang dengan presentase $60 \%$ - 69\% dan kategori sangat kurang dengan presentase $<59 \%$. Jika ketuntasan klasikal siswa telah mencapai $80 \%$ dari seluruh siswa, maka keterampilan menulis siswa secara klasikal telah tercapai dengan baik.

Learning kelas III di SDTI 030 Batu Belah pada siklus I dan siklus II terdapatnya peningkatan pada keterampilan menulis puisi menggunakan model Experiential Learning kelas III SDTI 030 Batu Belah. Diketahui bahwa nilai ratarata siswa pada siklus I meningkat menjadi 70,05\% dengan kategori cukup (70\%-79\%), kemudian pada siklus II mengalami peningkatan menjadi $80,00 \%$ dengan kategori baik (80\%-89\%). Sedangkan presentase ketuntasan klasikal keterampilan menulis pusi pada siklus I meningkat menjadi $60,00 \%$ dengan kategori kurang (60\%-69\%), kemudian pada siklus II meningkat menjadi $85,00 \%$ dengan kategori baik 
(80\%-89\%). Untuk mengetahui perekembangan keterampilan siswa dari sebelum tindakan, siklus I dan II pada siswa kelas III SDTI 030 Batu Belah secara jelas dapat dilihat tabel berikut ini.

Berdasarkan tabel 4.5 menunjukkan bahwa nilai ratarata kelas dari data awal 58,83 meningkat pada siklus I menjadi 60,00 dan siklus II menjadi 78,80. Begitu juga dengan ketuntasan secara klasikal dari data awal $29 \%$ meningkat pada siklus I 56\% dan meningkat lagi pada siklus II menjadi $92 \%$ dan untuk mengetahui secara jelas

\section{Gambar 4.1}

(Grafik Perbandingan Nilai Siswa Pratindakan, Siklus I dan Siklus II)

Dilihat dari diagram di atas, dapat dilihat hasil keterampilan menulis puisi baik secara klasikal maupun secara nilai rata-rata yang diperoleh siswa mengalami peningkatan.

Berdasarkan dari hasil penelitian yang telah dilakukan, maka beberapa hal yang akan dibahas terkait penelitian ini adalah:

\section{Perencanaan Peningkatan Keterampilan menulis puisi Dengan Menggunakan Model Pembelajaran Experiential Learning}

Pada perencanaan pelaksanaan siklus I dan siklus II dalam pembelajaran Bahasa Indonesia pada materi puisi pada siswa kelas III SDN TI 030 Batu Belah, perencanaan pembelajaran peningkatan setiap tindakan dapat dilihat pada grafik di bawah ini:

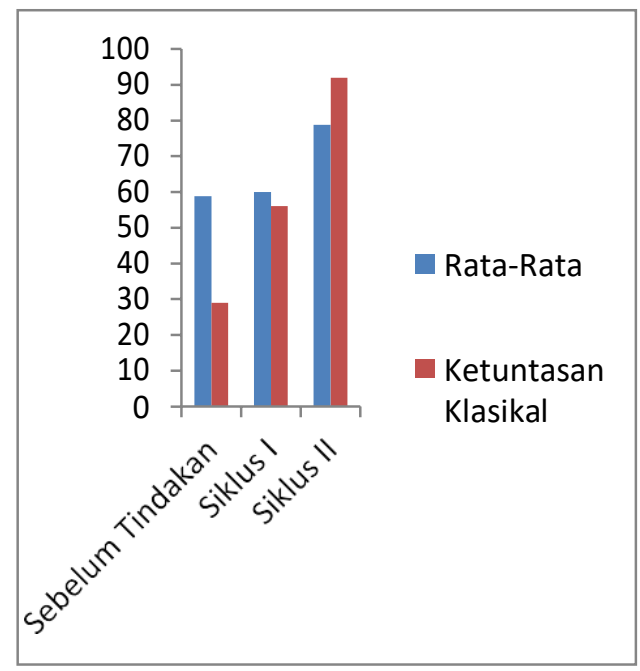

perlu dibuat sebagaimana yang dikemukakan (Suyatno, 2009) setiap guru pada satuan pendidikan berkewajiban menyusun RPP secara lengkap agar pembelajaran berlangsung secara inspiratif, menyenangkan, menantang, memotivasi peserta didik untuk berpartisipasi aktif, serta memberikan kreativitas, dan kemandirian sesuai dengan bakat dan minat.

Sebelum melakukan tindakan, peneliti terlebih dahulu harus membuat perencanaan karena proses pembelajaran perlu direncanakan, seperti yang dikemukakan (Arikunto, 2015) seorang guru dapat melakukan perencanaan dalam membuat PTK seperti merancang skenario pembelajaran, dan menetapkan indikator pencapaian, serta menyusun instrumen penelitian. Adapun perencanaan yang 
disusun oleh peneliti dalam penelitian ini adalah, menyusun silabus, menyusun RPP berdasarkan tahapan pada model Experiential Learning yaitu, mempersiapkan lembar observasi aktivitas guru, mempersiapkan lembar observasi aktivitas siswa, meminta guru kelas yaitu ibu Darmilis,S.Pd untuk menjadi observer I mengamati aktivitas guru dan meminta kesediaan teman sejawat yaitu Rosdiana Sri Devi untuk menjadi observer II mengamati aktivitas siswa, serta mempersiapkan lembar tugas siswa.

Adapun komponenkomponen penting yang ada dalam rencana pembelajaran meliputi: identitas sekolah, standar kompetensi (SK), kompetensi dasar (KD), Indikator, tujuan pembelajaran, materi pokok, penerapan langkah-langkah model Experiential Learning, sumber pembelajaran, dan penilaian. Berdasarkan dari penilaian yang dilakukan oleh observer I terhadap perencanaan yang dilakukan oleh peneliti pada siklus I adalah persiapan yang dilakukan oleh guru praktisi seperti kesesuaian antara indikator dengan SK dan KD sudah sesuai, kemudian pemilihan materi ajar telah sesuai dengan tujuan pembelajaran, pemilihan materi ajar telah sesuai dengan karakteristik peserta didik, serta kesesuaian antara pemilihan materi ajar dengan alokasi waktu juga sudah sesuai.

Secara keseluruhan, penilaian dalam perencaan ini sudah lumayan baik meskipun masih perlu diperbaiki lagi. Sedangkan pada siklus II penilaian yang diberikan oleh observer I terhadap perencanaan yang telah dilakukan adalah kesesuaian antara indikator dengan SK dan KD nya sudah sesuai, kemudian pemilihan materi ajar telah sesuai dengan tujuan pembelajaran, pemilihan materi ajar telah sesuai dengan karakteristik peserta didik, serta kesesuaian antara pemilihan materi ajar dengan alokasi waktu juga sudah sesuai.

\section{Skenario}

pembelajaran telah sesuai dengan metode yang digunakan yaitu model Experiential Learning. Berdasarkan penilaian tersebut dapat disimpulkan bahwa perencanaan yang dilakukan oleh peneliti pada siklus II ini sudah jauh lebih baik daripada siklus sebelumnya.

2. Proses Pembelajaran Bahasa Indonesia Pada Materi Puisi Dengan Menggunakan Model Experiential Learning.

Berdasarkan hasil pelaksanaan pada siklus I, pembelajaran masih belum maksimal. Siswa diharapkan dapat bertanggung jawab ketika diberikan tugas. Ini dikarenakan kurangnya pengawasan guru terhadap 
siswa ketika siswa sedang mengerjakan tugas, sehingga siswa masih ada yang tidak bekerja dalam menyelesaikan tugasnya. Kemudian penyebab lainnya adalah siswa masih bersifat pasif ketika pembelajaran berlangsung, maksudnya siswa masih belum berani mengemukakan pendapatnya ketika guru memberikan pertanyaan seputar materi yang diajarkan.

Keterampilan

menulis siswa masih rendah ketika menuangkan ide, dan juga ketika menulis puisi juga masih belum sesuai dengan aspek-aspek dalam penilaian keterampilan menulis. Dalam hal ini, guru perlu melakukan bimbingan yang lebih terhadap siswa, agar siswa merasa nyaman sehingga berani menyampaikan ide dan pendapatnya terkait pembelajaran.

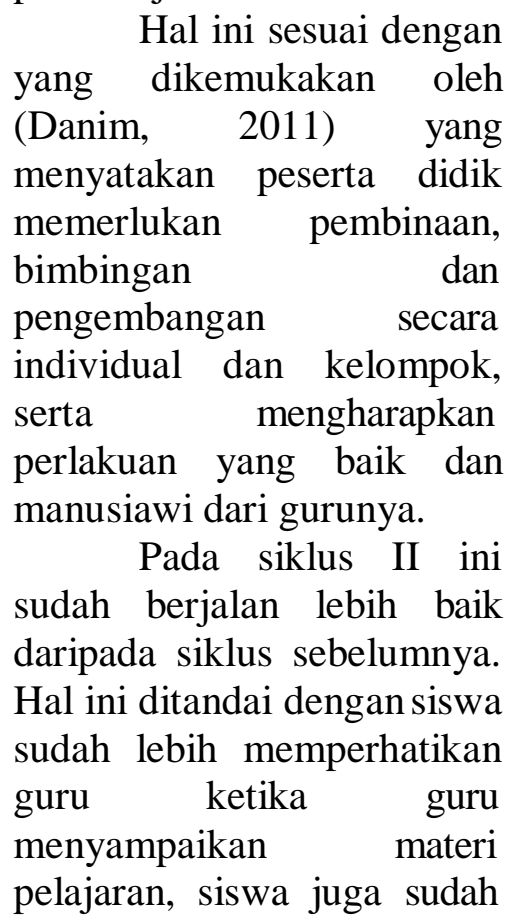

lebih aktif dalam proses pembelajaran dan berani mengemukakan pendapatnya atau menjawab pertanyaan yang diberikan oleh gurunya. Hal ini sesuai dengan yang disampaikan oleh (Hamalik, 2013) yang menyatakan bahwa bukti bahwa seseorang telah belajar adalah terjadinya perubahan tingkah laku pada orang tersebut, misalnya dari tidak tahu menjadi tahu, dari tidak mengerti menjadi mengerti. Pada siklus II ini siswa juga sudah mampu dalam mengerjakan tugas pada pelajaran Bahasa Indonesia pada materi puisi sudah mengalami peningkatan . Berdasarkan hasil pelaksanaan pada siklus I hingga siklus II ini, keterampilan berbicara siswa pada pembelajaran Bahasa Indonesia materi puisi dengan menggunakan model Experiential Learning mengalami peningkatan pada siswa kelas III SDN TI 030 Batu Belah.

\section{Peningkatan Keterampilan menulis Siswa Dengan Menggunakan Model Experiential Learning.}

Berdasarkan dari data sebelum diterapkannya model Experiential Learning, diketahui bahwa hasil belajar siswa terhadap pelajaran Bahasa Indonesia pada materi puisi masih kurang, yaitu dengan ratarata 58,83, sedangkan ketuntasan klasikalnya yaitu 29\%. Hal ini disebabkan karena selama ini guru masih 
menggunakan metode lama, dan pembelajaran hanya terfokus pada guru sedangkan siswa hanya mencatat pada buku catatan, sehingga siswa menjadi merasa bosan. Hal ini seperti yang diungkapkan oleh (Daryanto, 2009) salah satu faktor yang mempengaruhi hasil belajar siswa berasal dari luar atau eksternal, misalnya metode belajar dan mengajar. Jika guru tidak mampu menerapkan metode mengajar yang menarik, maka siswa akan cepat merasa bosan dan semangat belajarnya menjadi menurun. Hasil keterampilan menulis siswa pada siklus I mengalami peningkatan dari sebelumnya yaitu dari 58,83 menjadi 60,00. Pada siklus ke II, rata-rata hasil belajar siswa adalah 78,80. Dari 25 orang, sebanyak 23 orang telah mencapai ketuntasan secara individual, sedangkan ketuntasan siswa secara klasikal telah mencapai $85 \%$ atau hanya 2 orang saja yang tidak tuntas penyebabnya siswa tidak pandai menulis dan asik bermain di kelas sewaktu guru menerangkan pelajaran. Secara klasikal, hasil belajar siswa telah mencapai kriteria yang telah ditetapkan. Berdasarkan ketuntasan klasikal di atas, dapat disimpulkan bahwa nama siswa yang tidak tuntas pada siklus II ini sama dengan nama siswa yang tidak tuntas pada siklus pertama, yaitu AF dengan nilai pada siklus I adalah 60 , dan nilai pada siklus ke II adalah 60. Kemudian ada ZR dengan nilai pada siklus I adalah 60, ada NK dengan nilai pada siklus I adalah 60 dan pada siklus kedua adalah 50, dan siswa yang bernama FA dengan nilai siklus adalah 55.

Penyebab siswa tersebut tidak tuntas adalah karena pada saat pembelajaran berlangsung mereka asyik bermain dibangku mereka yang jaraknya berdekatan, kemudian kepercayaan diri siswa tersebut juga rendah, mereka tidak mau ketika diminta oleh guru untuk menyampaikan pendapat. Penyebab siswa yang tuntas mereka dilatih terus untuk menulis sebuah puisi. Selain itu, penyebab hasil belajar siswa dapat dipengaruhi oleh beberapa faktor. Hal ini juga di ungkapkan oleh (Daryanto, 2009) bahwahasil belajar siswa dipengaruhi oleh faktor internal dan eksternal.

Dalam meningkatkan keterampilan menulis puisi siswa, pemilihan model pembelajaran yang tepat sangat berpengaruh terhadap hasil belajar siswa. Salah satu pemilihan model yang tepat untuk pembelajaran Bahasa Indonesia berdasarkan hasil tindakan yang telah dilakukan, model Experiential Learning memberikan dampak positif terhadap keterampilan menulis siswa. 


\begin{abstract}
Berdasarkan hasil pembahasan di atas dapat disimpulkan bahwa penerapan model Experiential Learning dapat meningkatkan keterampilan menulis puisi siswa pada materi puisi kelas III SDTI 030 Batu Belah tahun ajaran 2019/2020.
\end{abstract}

\section{SIMPULAN}

Berdasarkan hasil analisis data perencanaan, proses dan hasil keterampilan menulis puisi siswa dengan menggunakan model Experiential Learning pada siklus I dan siklus II. Perencanaan pembelajaran Bahasa Indonesia materi menulis puisi peneliti menyiapkan seperti silabus dan RPP, selanjutnya instrument penelitian berupa lembar penilaian perencanaan, lembar aktivitas guru, lembar aktivitas siswa, dan LTS. Peneliti juga meminta kesediaan guru kelas sebagai observer I untuk mengisi lembar aktivitas guru dan lembar penilian perencanaan, observer II untuk mengisi lembar observasi siswa dan peneliti sendiri sebagai guru praktis di dalam kelas.

Tahap pelaksanaan tindakan merupakan implementasi dari tahap perencanaan. Pelaksanaan tindakan dilakukan pada proses pembelajaran secara terstruktur sesuai dengan indikator yang harus dicapai berdasarkan Rencana Pelaksanaan Pembelajaran (RPP) dengan penerapan model Experiential Learning. Pada tahap pelaksanaan tindakan terdiri dari kegiatan awal, kegiatan inti dan kegiatan akhir.

Keterampilan menulis puisi siswa kelas III SDTI 030 Batu Belah, nilai rata-rata siswa pada pratindakan adalah 57,40 dengan kategori Sangat kurang $(<55 \%)$ pada siklus I meningkat menjadi 70,05 dengan kategori cukup (70\%-79\%), kemudian pada siklus II mengalami peningkatan menjadi 81,05 dengan kategori baik (80\%-89\%). Sedangkan presentase ketuntasan klasikal keterampilan menulis pusi pratindakan adalah $18.75 \%$ (11 siswa) dengan kategori kurang sekali $(<59 \%)$, pada siklus I meningkat menjadi $60,00 \%$ (12 siswa) dengan kategori kurang (60\%-69\%), kemudian pada siklus II meningkat menjadi $85.00 \%$ (17 siswa) dengan kategori baik (80\%-89\%).

Berdasarkan hasil peneitian di atas, maka saran peneliti yang berhubungan dengan penelitian ini adalah sebagai berikut:

1. Untuk meningkatkan hasil keterampilan menulis puisi bebas siwa kelas III, disarankan guru SDTI 030 Batu Belah dapat model Experiential Learning .

2. Untuk meningkatkan kualitas pembelajaran, disarankan kepada guru SDTI 030 Batu Belah dapat model Experiential Learning.

3. Untuk meningkatkan kualitas sekolah, disarankan kepada sekolah untuk lebih mengawasi proses pembelajaran di kelas, agar kegiatan belajar mengajar yang dilaksanakan guru dapat dilaksanakan dengan baik.

\section{DAFTAR PUSTAKA}

Arikunto, dkk. (2014). Penelitian Tindakan Kelas. Jakarta : Bumiaksara.

Abbas. (2006). Pembelajaran Bahasa Indonesia yang Efektif di Sekolah Dasar. Jakarta : Depdiknas

Budiman N. N. (2012). Etika Profesi Guru. Yogyakarta : Mentari Pustaka

BNSP. (2006). Isi, Tujuan dan Ruang

$\begin{array}{lcc}\text { Lingkup } & \text { Kurikulum } & \text { Tingkat } \\ \text { Satuan } & \text { Pendidikan } & \text { (KTSP) } \\ \text { Sekolah } & \text { Dasar. } & \text { Jakarta: } \\ \text { Depdiknas } & & \end{array}$

Maryanto. (2013). Peningkatan Ketrampilan Menulis PuisiMelalui Model Experiential 
Learning Pada Siswa Kelas III.

Universitas Negri Semarang:

Nurgiantoro, Burhan.

(2010).

Penilaian Pembelajaran Bahasa.

Yogyakarta : BPFE-Yogyakarta.

Pebriana, P.H. (2017). Peningkatan

Keterampilan Menulis Puisi

Bebas Menggunakan

Pendekatan Kontekstual Siswa

Sekolah Dasar. Jurnal Publikasi

Pendidikan Volume 7 Nomor 2,

Juni 2017.

Peraturan Mentri Pendidikan Nasional

Republik Indonesia Nomor 22

Tahun 2006 Tentang Standar

Isi Untuk Satuan Pendidikan

Dasar Dan Menegah. 2006.

Jakarta Diperbanyak oleh PT

Armas Duta Jaya.

Silberman, Mel. 2014). Experiential

Learning. (Handbook

Experiential Learning).

Penerjemah: M. Khozim.

Bandung: Nusa Media.

Suyatno. (2009). Menjelajah

Pembelajaran Inovatif.

Sidoarjo: Masmedia Buana

Pustaka.

Trianto. (2013). Model Pembelajaran

Terpadu, Konsep, Strategi dan

Implementasi dalam Kurikulum

Tingkat Satuan Pendidikan

(KTSP). Jakarta.

Tarigan, (2008). Menulis Sebagai

Suatu Keterampilan Berbahasa.

Bandung : Angkasa. 